\title{
Thousand Colony Forming Units
}

National Cancer Institute

\section{Source}

National Cancer Institute. Thousand Colony Forming Units. NCI Thesaurus. Code C68895.

A unit of viable cell quantity equal to $10 \mathrm{E} 3$ colony forming units (10E3 CFU). 